DOI 10.15826/qr.2016.2.167

УДК 821.112.2Гервег-15+821.161.1Герцен-312.6+929Гервег

\title{
THE PERCEPTION OF G. HERWEGH'S PERSONALITY AND WORK IN RUSSIAN CULTURE: FROM REVOLUTIONARY SPIRIT TO A SCANDALOUS LOVE AFFAIR*
}

\author{
Lidia Dmitrieva \\ Natalia Nikonova \\ Tomsk State University, \\ Tomsk, Russia
}

This paper offers an overview of the perception of work and the evaluation of the personality of $19^{\text {th }}$ century German poet Georg Herwegh. The research demonstrates that the character of perception is determined by the cultural and historical context in the receiving culture, and it is even more so with political poetry that is based on the rhetoric of spiritual edification. The analysis is made with reference to previously unstudied materials, namely, marks and notes from the archive of V. A. Zhukovsky made on the pages of Herwegh's most popular book. On the basis of this material the authors conclude that this period was characterised by the initial attempt to represent Herwegh and his poetry within the framework of the history of German literature from its emergence to the mid- $19^{\text {th }}$ century. The second period of Russian authors' reference to his poetry was dominated by the appearance in Russia of the ideological tonality typical of the political poems that won the German poet his fame. The beginning of this period was the post-revolutionary decade of the 1820s. Russian literature specially turned to Herwegh's legacy, thus marking a new stage of perception by publishing Selected Poems, a new voluminous anthology of translations of his works, as well as a number of literary studies. A new burst of attention began between 2009 and 2013 when numerous articles on the relationship between the Herzens and Herwegh were published. Post-Soviet Russian scholars have examined the controversial personality of the German author through a lens which has brought new traits to the fore: the love triangle between Herwegh and the Herzens which was the main prototype of the conflict in Herzen's

* Citation: Dmitrieva, L., Nikonova, N. (2016). The Perception of G. Herwegh's Personality and Work in Russian Culture: From Revolutionary Spirit to a Scandalous Love Affair. In Quaestio Rossica. Vol. 4. № 2, p. 195-205. DOI 10.15826/qr.2016.2.167.

Цитирование: Dmitrieva L., Nikonova N. The Perception of G. Herwegh's Personality and Work in Russian Culture: From Revolutionary Spirit to a Scandalous Love Affair // Quaestio Rossica. Vol. 4. 2016. № 2. P. 195-205. DOI 10.15826/qr.2016.2.167.

The article is supported by the Russian Foundation for the Humanities (Project 16-0450012) and a grant from the President of the Russian Federation (MD-4756.2016.6). 
My Past and Thoughts. The paradigmatic shift in the perception of the German poet connected with the change from the textual to the biographic discourse is directly reflected in Russian mass literary culture.

Keywords: V. A. Zhukovsky; G. Herwegh; A. I. Herzen; literary perception; biographical paradigm.

Рассматривается динамика восприятия и трактовки личности и наследия немецкого поэта XIX в. Георга Гервега в России. Исследование вопроса показывает, что характер рецепции определялся культурно-исторической ситуацией в принимающей культуре, особенно в политической поэзии, которая основана на риторике духовного назидания. В научный оборот впервые вводится материал помет и автографов из архива Василия Андреевича Жуковского на страницах издания самой популярной книги Гервега. На основании данного материала выдвигается положение о том, что в начальный период восприятия поэзия Гервега осмыслялась только в контексте немецкой литературы от ее начала до середины XIX в., и ее рассмотрение давало материал для истории немецкой литературы. Второй этап активного обращения отечественной словесности к его наследию связан с приходом и воцарением в России того идейного пафоса, который был характерен для политических стихов, определивших скандальную популярность немецкого поэта. Начало этого периода связано с послереволюционным десятилетием 1820-х гг. Русская литература обратилась к наследию Гервега специально, обозначив новый этап рецепции крупной антологией свежих переводов его стихов «Избранное» и рядом литературоведческих трудов. Новый всплеск внимания к Гервегу в истории русской литературы и гуманитарной мысли ознаменовался выходом в 2009-2013 гг. сразу нескольких работ, посвященных отношениям немецкого поэта с А. И. Герценом и его супругой Натали. В постсоветской русистике неоднозначная и неординарная личность немецкого поэта приобрела новые черты, внимание сосредоточилось на любовном треугольнике Герцены - Гервег, послужившем главным прототипом конфликта для «Былого и дум». Парадигматический слом в осмыслении фигуры немецкого поэта, связанный со сменой текстуального дискурса на биографический, напрямую отразился и в русской массовой словесной культуре.

Ключевые слова: В. А. Жуковский; Г. Гервег; А. И. Герцен; рецепция; биографическая парадигма.

The summer of 1841 was marked by a literary sensation in the German world. The first part of the collection of poems by the 24 year-old Georg Herwegh (1817-1875), entitled Gedichte eines Lebendigen, ${ }^{1}$ was published in Zurich. The book had an intoxicating effect and a powerful impact both on conservatives and liberals. It was a new kind of political poetry that was based almost exclusively on a rhetoric derived from pietist

${ }^{1}$ Poems of a Living Man - hereinafter translated by Lidia Dmitrieva. - L. D., N. N. 
preaching. Herwegh proved to be very popular in the pious Germany of the Biedermeier period, a tremendously productive era in the history of German literature. Herwegh was understood by both opposing parties, since he had adopted a poetical strategy that allowed him to hedge his bets: the "Stuermer" and radical tonality of his verse was based on the plots and composition structures of edificatory literature, romantic natural philosophy, and mythopoetics. The unpretentious language which he used to express the eternal struggle against tyranny and his call for unity, protest, and liberation in Germany made his poetry accessible to the general reader. The life-affirming tonality that predominated the work could be already be in discerned

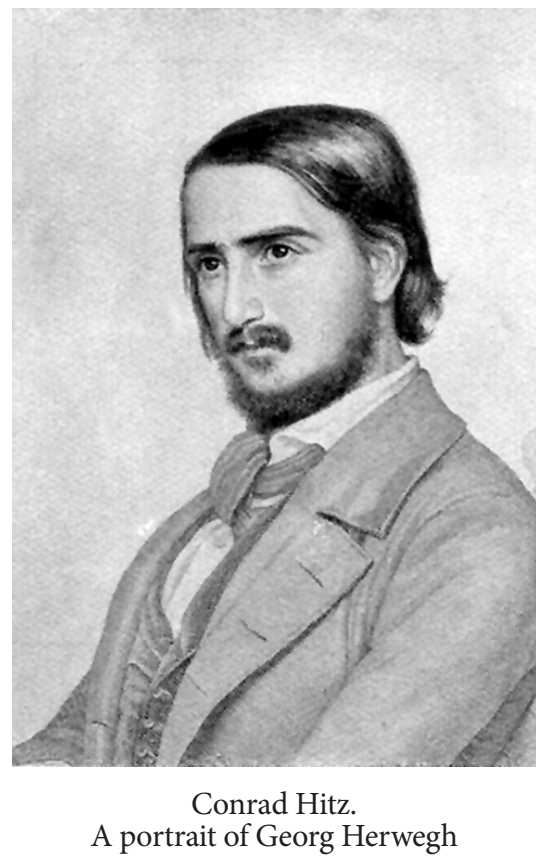
in the title, which hinted at Briefe eines verstorbenen ${ }^{2}$ by Hermann von Pückler-Muskau, a German prince, travel writer, major in the Russian army, and founder of Europe's largest English-style park. His works were familiar to V. A. Zhukovsky, who read the four-volume Briefe eines verstorbenen. Ein fragmentarisches Tagebuch aus England, Wales, Irland, Frankreich, Deutschland und Holland, geschrieben in den Jahren 1826$1829,{ }^{3}$ the book which incited Herwegh's polemics.

The young poet was not satisfied with the romantic irony of PücklerMuskau, which he considered to be detached from the realities of the day. Unlike the latter, who was not widely known in Germany and did not aspire to notoriety, Herwegh became famous overnight. The most well known of his contemporaries responded immediately to his sensational debut: A. Ruge designated Herwegh 'an apostle of modernity', while Heine, ironically warning the fledgling poet, called him 'the iron lark'.

The first volume of Gedichte eines Lebendigen was reprinted six times in less than two years (1841-1843) and achieved a considerable circulation (from 1,000 to 6,000 copies). Herwegh's success was encouraged not only by slogans taken from the poems for propaganda purposes, but also by his outrageous treatment of both sides of political high society. Zhukovsky possessed the second edition of this new book. Despite the general revolutionary mood of the collection, one could also find within it a paean to the king, sonnets without political overtones, and dedications

\footnotetext{
${ }^{2}$ Letters of the Dead.

${ }^{3}$ Letters of the Dead. Fragments from the Diary made in England, Wales, Ireland, France, Germany and Holland in 1826-1829.
} 
to Gutenberg, Uhland, and Buchner. While the preaching rhetoric of the author, the son of a priest who had failed to finish his studies at the Faculty of Theology in Tübingen, was certainly one of the reasons for the work's massive success, it was also the subject of devastating critiques: his companions in the revolution accused him of using plain images and his fellow writers mocked at him. However, the recognisable forms and rhetoric of edificatory literature allowed him to be understood by the majority of readers raised in the pietist literary culture of Prussia, which was virtually regulated by the state. It is unlikely that the poet or his Russian reader ever imagined that the ephemeral ideas expressed in the poems would be implemented: however, this happened in Germany only seven years after the first part of the cycle had come out.

It is essential to consider the various images of the German author perpetuated in the history of Russian literature and thought. At least three models of perception can be found in the literature devoted to him. The first belongs to the German tradition, where Herwegh was popular in the 1990s, as shown by at least two monographs on the subject [Krausnick]. The authors of these works are to a certain extent polemical. In the book by M. Krausnick, published in 1993, Herwegh's poetry was defined as a transient product of the revolutionary era, unimaginatively reflecting new political trends and harping on clichés which became slogans. In William Entsenberger's book, Herwegh was represented as a hero, a fact thoroughly demonstrated by the title of his repeatedly republished work: Herwegh. Ein Heldenleben [Enzensberger]. ${ }^{4}$ However, no German philologist has offered an opinion on the non-political aesthetics of the author and the role he played in the history of Russian literature through his dramatic association with Herzen and his family.

\section{A. Zhukovsky as the founder of Herwegh's perception}

There is no doubt that the first Russian romanticist V. A. Zhukovsky, a contemporary of Herwegh and Frederick William IV and witness to the events of the 1840s, stood at the origins of Herwegh's perception in Russia: he had been steadily introducing the "German text" into Russian print media during this period [Nikonova]. Zhukovsky's personal library is of considerable interest for scholars, containing as it does an edition of Herwegh's poetry which he carefully studied and commented upon. This copy deserves special attention because it reveals to us the little-known details of Zhukovsky's participation in the literary life of contemporary Germany.

It is logical to assume that Zhukovsky discovered his interest in the newly-minted celebrity after Herwegh visited King Frederick William IV, who had friendly relations with the mentor of the Russian monarch. This visit was used in ideological articles as an example of a 'politically incautious act', since it demonstrated Herwegh's insufficiently revolutionary views. The

${ }^{4}$ Herwegh $G$. Life of the Hero. 
audience with Frederick William damaged Herwegh's reputation among his fellow party members: the desire to restore his popularity led to defiant attacks against the monarch, who then banned his planned periodical along with many other radical newspapers.

The subsequent exile to Switzerland meant the end of Herwegh's resounding success. It was during these events in 1842 that Zhukovsky found the time to carefully study Gedichte eines Lebendigen.

His edition is full of notes, a fact which allows us to speak about the original perception strategy of the reader. Alongside the initial broadside of the book is a three-line inscription by Zhukovsky: it indicates a thoughtful and repeated reading with the aim of gaining an insight into the essence of the new political poetry. He documented the process and results of his immersion:

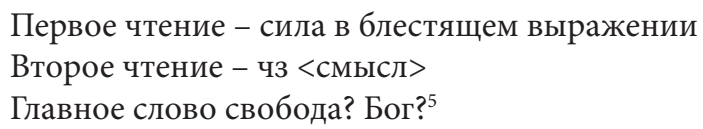

These handwritten lines record both the process and the result of Zhukovsky's interpretation of Herwegh's rhetoric. In the first line, the Russian poet appreciates the talent of the author, defining his phrasing as 'brilliant'. The second line outlines the debate which is expressed in the reader's marks later on in the book, while the third line represents the crucial philosophical and aesthetic dialectic of Herwegh's art: the paradoxical relationship between his utopian concept of 'freedom' (Herwegh does not specify whom or what he wanted to free) and the various conventional markers of edificatory literature. This essential feature of the poetic world of Herwegh has not attracted enough attention from those studying his literary legacy.

Foreign studies have noted that one of the strong points of his rhetoric was that he followed the rules of the preaching genre, which was aimed at fascinating, instructing, convincing, and appealing to the flock through the life-giving word alone. However, the majority of the central texts in this book use the traditions of spiritual and edifying literature as a stage for revolutionary enthusiasm. Almost all of these poems were marked by Zhukovsky, including:

Arndt's Wiedereinsetzung (Arndt's Return to the Throne)

Gebet (Prayer)

Das freie Wort (Free Speech)

Protest (Protest)

Aufruf (Call)

Neujahr (New Year)

${ }^{5}$ First reading - the power in a brilliant expression. Second reading - 'meaning'. Is the key word freedom? God? 
The first of the above list was not popular in Russia because of the need to provide Soviet readers with endless commentaries explaining how and why the progressive oppositionist mentioned Johann Arndt, the famous preacher and central figure of German pietism whose books were available in almost every German household in the $18^{\text {th }}$ and $19^{\text {th }}$ centuries. In this poem Herwegh decried Arndt's 'return to the throne' (Wiedereinsetzung) when the Prussian government started actively sponsoring pietst literature in the 1840 s.

The subtext of Herwegh's political poetry contains an outright protest against the domestic piety promoted by Friedrich Wilhelm IV in the early 1840s. It was this very feature that V. A. Zhukovsky noticed when he posed the question: 'Is the key word freedom? God?'

If we examine the marginalia, we can see the receptive strategy of Zhukovsky as a reader. Firstly, he does not accept the aesthetic manifesto of Herwegh given in the first 20 texts marked by Zhukovsky. This positive denial relates only to the meaning and plots of the poems, not the form.

Both the political and romantic poems captured the attention of the Russian romanticist. The texts marked by Zhukovsky develop the theme of the poet and poetry: the elaboration of this subject impressed the reader, as it reminded him of his own style. Mountain and sea views, cemeteries, elegiac depictions of earthly impermanence, ruminations on the indivisibility of life and death, the ontology of the natural landscape and its merger with the soul in poetic creativity: all of these features in Herwegh's sonnets resounded deeply with Zhukovsky's romanticism.

We must mention the two-part poem Ufnau und St. Helena. Zhukovsky noted the poem with the acronym 'NB', and its imagery has obvious similarities with one of his last poems, To the Russian Giant (К русскому великану) (1848). Through the islands of St. Helena and Ufnau, Herwegh depicted Germany and France.

\section{The early perception of Herwegh's poetry}

In Russia, Herwegh's works were conceptualised gradually. The nature of the perception was determined, as often happens, by the prevalent historical and cultural environment in the host country. The initial period of perception between the 1870s and the 1900s is associated with the first attempt of the famous writer, translator, publisher, and poet N. V. Herbel (1827-1883) to present Herwegh and his poetry within the context of the history of German literature. Five poems by Herwegh were included in his anthology German Poets with their Biographies and Samples (Немецкие поэты в биографиях и образцах) [Гербель]: these pieces were translated by P. Weinberg, A. Pleshcheev, M. Mikhailov, N. Grekov, and I. Kreshev. However, the introductory note by Gerbel himself is perhaps even more important. It outlines Herwegh's biography and his artis- 
tic style, emphasising the brightest features of his poetry from a literary perspective whilst paying little attention to the poet's participation in conservative or revolutionary movements. Gerbel gave the most intelligent, objective, and complete literary portrait of Herwegh in the whole century and a half of Russia's perception. As we will see, later writers discussing Herwegh gave the perception an obvious subjective coloring, thereby reflecting the ideas of the recipients themselves.

\section{The second period of Herwegh's perception}

The second period of Russia's perception of 'the iron lark' was characterised by the ideological fervor that engulfed Russia in the first decades of the Soviet Union: unsurprising, it was his scandalous political poetry which received the most attention. In the post-revolutionary decade of the 1920s, the Russian reader gained access to Boris Pasternak's 1925 translation of Gedichte eines Lebendigen, the repeatedly republished anthology of articles by the German scholar Mehring (Die Welt Literatur und Proletariat, 1925), ${ }^{6}$ and P. K. Huber's novel The Whirling Heart. The Family Drama of the Herzens (1928). So the full perception of Herwegh began with Gedichte eines Lebendigen, the most representative, but also the most ambiguous cycle. The new image of Herwegh was strongly framed by the ideological objectives and political propaganda of the revolutionary upsurge in the 1920s.

In the late 1940s, on the hundredth anniversary of the revolutionary events witnessed by Zhukovsky, a new volume of German political poetry was released in Soviet Russia: Herwegh's verses were not the least important. Indeed, his poems in the anthology outnumbered those of $\mathrm{H}$. Heine, although these were positioned first. Most of the translations (29 of 34) were written by N. L. Verzheyskaya (1903-1985): the well-known professionals A. Argo (A. Goldenberg, 1897-1968) and L. M. Penkovsky (1894-1971) also participated in the work. The translating strategy was generally loose in terms of how it rendered Herwegh's ideas and style. As S. Ter-Minasova has remarked, the general social tendency in Russia at that time was the aspiration to equality, which 'led to an obvious lack of diversity: levelling people, ignoring their individuality, their individual needs, problems, likes, and dislikes' [Ter-Minasova, p. 11]. Meagre as they were, the cultural and historic genesis and philosophical foundations of the German poet's lyrical world were flattened out and truncated, and thus brought closer to the reality confronted by most Soviet readers. As a result, the poems of Herwegh' in this collection can be read as exemplary propaganda for domestic consumption. In this edition, I. V. Mirimsky, the famous translator and scholar of Russo-European literary relations was the author of the comments and the introductory article German Poetry of the 1848 Revolution. Here, Herwegh was represented as 'a talented singer of the dawn of the German

\footnotetext{
${ }^{6}$ World Literature and the Proletariat.
} 
revolution of 1848', in whose verse was 'an optimistic rush to the sun, a cheerful pagan sensuality, and a multicoloured spring are combined with an enthusiastic love for the people and a passionate hatred for their oppressors' [Немецкая поэзия революции 1848 года, с. 10-11].

\section{Herwegh and his poems in Soviet Russia (1950s-1990s)}

A decade later, Russian literature specifically addressed the heritage of Herwegh by publishing a large collection of his poems (Selected Works [Избранное], Moscow, 1958) and a number of literary works, with those by A. L. Dymshits and S. V. Turaev standing out in particular [Дымшиц; Тураев, 1959]. About a hundred poems were included in the collected edition, most from the first volume of Gedichte eines Lebendigen. The poet was presented from different perspectives: he was not only considered as a representative of radical politics, but also as the author of fully fledged artistic works. In the 1958 collection, one can find talented translations by B. L. Pasternak, modified or remodeled translations by N. L. Verzheyskaya, and the work of the masters of Soviet poetry translation L. V. Ginzburgand E. G. Etkind. In a detailed introductory essay by A. I. Deitsch, Herwegh and his activities are covered in depth: this history is concluded with the justified statement that 'His creative heritage was primarily formed by "Poems of a Living Man". They became part of the treasury of German national poetry' [Гервег, с. 9].

In the 1970s, articles on Herwegh were written for books on German literature, and thus tended to take a greater degree of critical distance. Thus, the authors of The History of Foreign Literature in the $19^{\text {th }}$ Century, although noting that 'the 1840s were the heyday of German revolutionary and democratic poetry', left a number of objective observations devoid of ideological content. For example, the authors state, firstly, that 'the success of Herwegh's poems collection is explained by the fact that the political subjects of most of the poems, their civilian and military message, were something unusual and new in the German poetry of those years and, secondly, that 'a larger proportion of abstraction is inherent in the tonality of Herwegh's poetry: the words "tyranny", "freedom" and others are not specified by the poet, they do not have the exact "addressee", they do not possess a social and political content of any historical accuracy' [Елисарова, Колесников]. S. V. Turaev's 1997 The Revolution in France and German Literature [Typaев, 1997], with its thorough study of the historical and cultural context of Herwegh's output, was to a certain extent definitive: many facts of his biography were clarified and the genesis of his poetic world was characterised.

\section{Herwegh in Russian thought and mass culture in the 2000s: the biographical turn to non-textual intimacy}

Herwegh was destined to gain new force in the history of Russian literature and thought half a century after the release of the Selected Works. 
The new surge of interest was marked by several texts released in 2009-2013 devoted to the relations of the German poet with A. I. Herzen and his wife Natalie. In post-Soviet studies, the controversial and eccentric personality of the German poet was seen in a new light as people focused their attention on the love triangle between the Herzens and Herwegh, which served as the main plot in $M y$ Past and Thoughts («Былое и думы»). Thus, in 2009 a voluminous essay entitled Herzen's Love Geometry by the writer and scholar V. A. Shirokov was published [Широков]. The author does not stint with the epithets that he piles onto the German poet: he was 'a picture of a man', 'LHomme Fatal to Herzen's wife', a person 'who

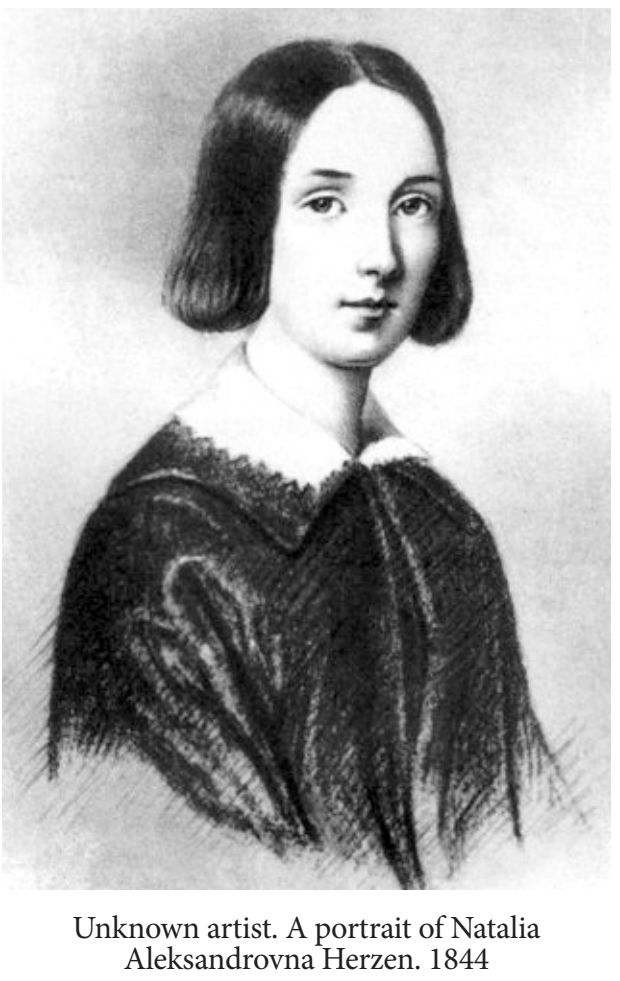
diligently ingratiated himself with his Russian friends' and thus practically killed them with his 'wimpishness'. He had 'commercial flair', but was prone to 'wordy and false outpourings' [Широков]. However, Shirokov makes it clear that Herwegh's role in the history of the Russian intelligentsia is substantial. This thesis was developed in 2010 by I. A. Paperno in her article Intimacy and History: Herzen's Family Drama in the Minds of Russian Intelligentsia [Паперно]. Paperno traces the sesquicentennial history of the family drama between the Herzens and Herwegh. She concludes that 'the history of Herzen's family drama became one of the cultural institutions of the Russian intelligentsia: the connection between intimacy and history became... reproducible in an individual's life' and that 'for many people friends, readers, researchers, writers - involvement in Herzen's family drama turned into an intimate experience. Thus, 'generations of researchers of Russian social thought and literature have been keenly interested in Herzen's family drama: this story is not over yet' [Паперно].

Indeed, the works that reputable scholars have penned about Herwegh are quite symptomatic of the paradigmatic fracture that occurred in the humanities and social sciences at the beginning of the $21^{\text {st }}$ century. The 'biographical turn'7 revived a genuine interest Herwegh, and in his love affairs as seen through the prism of Russian literary heritage and Herzen's My Past and Thoughts. This focus is being now duplicated in modern

\footnotetext{
${ }^{7}$ See: [The Turn to Biographical Methods; Подорога, с. 11-140].
} 
Russian mass culture. This re-writing of the history of literature and culture through immersion in an individual's private affairs immediately found resonance in the online writing community. In this respect, Herwegh's love triangle with the Herzens has provided abundant material.

In 2013, this plot provided the basis for L. Proshina's The Tempters: Herzen, Natasha, Herwegh: she is a permanent writer for the site Проза. py [Прошина]. The amount of research being conducted into the subject of temptation in the lives of writers has reached an all-time high. The same author has written about V. Hugo and C. O. Sainte-Beuve (Hugo - AdeleSainte-Beuve, published on 07.14.2013), A. Blok and A. Bely (Blok - Lyubov - Bugaev, published on 09.12.2013); V. I. Lenin and N. K. Krupskaya (Lenin - Krupskaya - Armand, published on 03.25.2014), and finally P. A. Vyazemsky (Peter Vyazemsky and Pushkin's Widow, published 06.08.2015). By the author's own admission, this series appeared thanks to a simple desire 'to understand, why temptation - this original sin - is possible'. The explanation is easily found in the essay on Herwegh and the Herzens: 'Herwegh decided to seduce Natasha...because he was envious of her husband'. Herzen's loss of his family in the affair designed by Herwegh and his wife Emma is considered to be the justified reward for his own betrayal when he seduced a married lady in Vyatka in his youth. In Proshina's essay, Herwegh is depicted through the lens of My Past and Thoughts. Thus a new Russian attitude towards Herwegh is being established in $21^{\text {st }}$-century mass culture: its contours are being defined by the demands of the information revolution.

\section{Список литературы}

Гервег Г. Избранное. М. : ГИХЛ, 1958. 240 с.

Дымшии А. Л. Карл Маркс и поэт Гервег // Уч. зап. Ленинград. пед. ин-та им. А. И. Герцена. 1958. Т. 170. Л., 1958. С. 333-350.

Елисарова М. Е., Колесников Б. И. История зарубежной литературы XIX века. М. : Просвещение, 1992 // Литература Западной Европы 19 века [сайт]. URL: http://19veuro-lit.niv.ru/19v-euro-lit/elizarova-izl/kriticheskij-realizm-xix-veka.htm (дата обращения: 20.04.2015).

Лобанов В. В. Библиотека В. А. Жуковского : (Описание). Томск : Изд-во Томск. ун-та, $1981.414 \mathrm{c}$.

Немецкая поэзия революции 1848 года / ред., автор предисл. и коммент. И. Миримский. М. : Худож. лит., 1948. С. 10-11.

Гербель Н. В. Немецкие поэты в биографиях и образцах. СПб. : Тип. В. Безобразова и $\mathrm{K}^{\circ}, 1871$.

Паперно И. А. Интимность и история: семейная драма Герцена в сознании русской интеллигенции (1850-1890-е годы) / авториз. пер. с англ. М. Долбилова // НЛО. 2010. № 103. URL: http://magazines.russ.ru/nlo/2010/103/pa3.html (дата обращения: 10.03.2015).

Подорога В. А. Материалы к психобиографии С. М. Эйзенштейна // Автобиография. К вопросу о методе : Тетради по аналитической антропологии. № 1 / под ред. В. А. Подороги. М., 2001. С. 11-140.

Прошина Л. Искусители : Герцен - Наташа - Гервег // Проза.py. URL: http://www. proza.ru/2013/07/22/1951 (дата обращения: 15.10.2015).

Тураев С. В. Творчество позднего Гервега // Вопр. лит. 1959. № 10. С. 169-185. 

214 c.

Тураев С. В. Революция во Франции и немецкая литература. М. : Наследие, 1997.

Широков B. А. Любовная геометрия Герцена // Наша улица. 2009. № 111 (2). URL: http://kuvaldn-nu.narod.ru/2009/02/shirokov-hertsen.htm (дата обращения: 10.03.2015).

Enzensberger U. Herwegh : Ein Heldenleben. Frankfurt am Main : Eichborn, 1999. $394 \mathrm{~S}$.

Herweg G. Gedichte eines Lebendigen : Mit einer Dedikation an den Verstorbenen. Zürich und Winterthur : Vierte Auflage, 1842. $168 \mathrm{~S}$.

Krausnick M. Die eiserne Lerche. Weinheim : Beltz \& Gelberg, 1998. 206 S.

Nikonova N., Dmitrieva L. Print Media as Socio-Imagological Tools: German world of V. A. Zhukovsky's "Herald of Europe" // International Conference on Research Paradigms Transformation in Social Sciences 2014. Procedia - Social and Behavioral Sciences, 166. Tomsk : National Research Tomsk State University Publ., 2015. P. 631-634.

Ter-Minasova $S$. G. The Dialectics of International Communication // XXV Annual Academic Conference, Language and Culture. Procedia, 154. Tomsk : National Research Tomsk State University Publ., 2014. P. 8-13.

The Turn to Biographical Methods in Social Science / Ed. P. Chamberlayne, J. Bornat and T. Wengraf. L.: Routledge, 2000.

\section{References}

Chamberlayne, P., Bornat, J. \& Wengraf, T. (Eds.) (2000). The Turn to Biographical Methods in Social Science. 368 p. London, Routledge.

Dymshits, A. L. (1958). Karl Marks i poet Gerveg [Karl Marx and Poet Herwegh]. In Uchenye zapiski, Vol. 170, pp. 333-350. Leningrad, Leningradsky gosudarstvennyy pedagogichesky institut im. A. I. Gertsena.

Elisarova, M. E. \& Kolesnikov, B. I. (1992). Istoriya zarubezhnoy literatury XIX veka [The History of Foreign Literature, $19^{\text {th }}$ Century]. Moscow, Prosveshchenie // Literatura Zapadnoy Evropy 19 veka. URL: http://19v-euro-lit.niv.ru/19v-euro-lit/elizarova-izl/kriticheskij-realizm-xix-veka.htm. (mode of access: 20.04.2015).

Enzensberger, U. (1999). Herwegh. Ein Heldenleben. 394 S. Eichborn, Frankfurt am Main.

Gerbel, N. V. (1871). Nemetskie poety v biografiyakh i obraztsakh [German Poets with Biographies and Samples]. Sankt Petersburg, V tipografii V. Bezobrazova i $\mathrm{K}^{\circ}$.

Herweg, G. (1842). Gedichte eines Lebendigen: Mit einer Dedikation an den Verstorbenen. Vierte Auflage. 168 S. Zürich und Winterthur.

Herweg, G. (1958). Izbrannoe [Selected Poems]. 240 p. Moscow, GIKhL.

Krausnick, M. (1998). Die eiserne Lerche. 206 S. Beltz \& Gelberg, Weinheim.

Lobanov, V. V. (1981). Biblioteka V. A. Zhukovskogo: (Opisanie) [The Library of V. A. Zhukovsky: A Description]. 414 p. Tomsk, Izdatel'stvo Tomskogo universiteta.

Mirimsky I. (Ed.) (1948). Nemetskaya poeziya revolyutsii 1848 goda (pp. 10-11) [German Poetry of the Revolution of 1848]. Moscow, Khudozh. lit.

Nikonova, N. \& Dmitrieva, L. (2015). Print Media as Socio-Imagological Tools: German world of V. A. Zhukovsky's "Herald of Europe". In International Conference on Research Paradigms Transformation in Social Sciences 2014. Procedia - Social and Behavioral Sciences, 166, pp. 631-634. Tomsk: National Research Tomsk State University Publ.

Paperno, I. A. \& Dolbilova, M. (Transl.) (2010). Intimnost' i istoriya: semeynaya drama Gertsena v soznanii russkoy intelligentsii (1850-1890-e gody) [Intimacy and History: The Herzen Family Drama in the Understanding of Russian Intelligentsia (1850-1890s)]. In NLO, 103. URL: http://magazines.russ.ru/nlo/2010/103/pa3.html (mode of access: 10.03.2015).

Podoroga, V. A. (2001). Materialy k psikhobiografii S. M. Eyzenshteyna [Materials to the Psychobiography of S.M. Eisenstein]. In Podoroga, V. A. (Ed.). Avto-biografiya. K voprosu o metode. Tetradi po analiticheskoy antropologii, 1, pp. 11-140. Moscow. 
Proshina, L. (n.d.). Iskusiteli : Gertsen - Natasha - Gerveg [Tempters. Herzen - Natasha-Herwegh]. In Proza.ru. URL: http://www.proza.ru/2013/07/22/1951 (mode of access: 15.10.2015).

Shirokov, V. A. (2009). Lyubovnaya geometriya Gertsena [Herzen's Love Geometry]. In Nasha ulitsa, 111 (2). URL: http://kuvaldn-nu.narod.ru/2009/02/shirokov-hertsen.htm (mode of access: 10.03.2015).

Ter-Minasova, S. G. (2014). The Dialectics of International Communication. In $X X V$ Annual Academic Conference, Language and Culture. Procedia, 154, pp. 8-13. Tomsk, National Research Tomsk State University Publ.

Turaev, S. V. (1959). Tvorchestvo pozdnego Gervega [Herwegh's Later Writings]. In Voprosy literatury, 10, pp. 169-185.

Turaev, S. V. (1997). Revolyutsiya vo Frantsii i nemetskaya literature [The French Revolution and German Literature]. 214 p. Moscow, Nasledie.

The article was submitted on 12.04.2016 